\title{
RECIPROCAL TRUSTS IN ESTATE AND GIFT TAXATION
}

A husband and wife each own income property; their children are approaching marriageable age. Can the husband and wife transfer their property to their children in trust, retain power to change beneficial interests and invade corpus, and yet not have the property included in their gross estates for estate tax purposes? Attempting to obtain an affirmative answer, a significant number of estate draftsmen ${ }^{1}$ have created "reciprocal" or "crossed" trusts. Under this arrangement, two or more grantors, at about the same time, create similar trusts; each grantor relinquishes personal control over corpus and income of the trust he creates, gives power to change beneficial interests and invade corpus to the other grantor, and receives similar powers over the corpus and income of the trust created by the other grantor.

Tax benefits would be a complete escape of estate taxation on the trusts, for neither grantor retains those interests or powers in his trust which would tie it to his gross estate, subject to the Commissioner's demands. ${ }^{2}$

However, in 1940, the famous Lehman v. Commissioner ${ }^{3}$ held that the trust created by the other grantor was to be included in the decedent's gross estate, on the theory that the decedent "in effect" was its settlor, retaming certain powers of control which justified inclusion of the trust in his estate.

To the confusion of all, subsequent application of the Lehman decision has developed a variety of divergent theories, ${ }^{4}$ with little agreennent on what facts are operative to define a taxable "reciprocal" trust. The Commissioner appears to think that simultaneous creation and a close or familial relation-

1 Estate "draftsmen" may be distinguished from the more expert estate "planners." In SHATTUCR, AN Estate PIANNER's HANDBOOK (1948), reciprocal trusts are not recommended for the factual situation described above. However, crossed insurance, whether or not part of a trust, is recommended for business partners, $i d$. at 62 , and crossed wills, perhaps incorporating an inter vivos trust, are recommended for young couples, id. at 8, 10. But cf. Note, Estate Tax Effect of Partners' Cross-Insurance and Purchase-Sale Agreements, 48 Cor L. REv. 450 (1948).

For the similar problem of inultiple trusts, see MacManus' Estate v. Commissioner, 172 F.2d 697 (6th Cir. 1949); Estate of A. Bluestein, 15 T.C. 770 (1950).

2 INT. REv. CODE § 811, "The value of the gross estate of the decedent shall be determined by including the value at the time of his death of all property ....

(c) (1) of which the decedent has at any time made a transfer ...

(B) under which he has retained ... (i) the right to the income from the property, or (ii) the right ... to designate the persons who shall possess or enjoy the property or the income therefrom ...

(d) of which the decedent has at any time made a transfer . . . by trust or otherwise, where the enjoyment thereof was subject at the date of his death to any change through the exercise of a power ... to alter, amend, revoke, or terminate."

3109 F.2d 99 (2d Cir.), cert. denied, 310 U.S. 637 (1940).

4 See generally 1 PadL, Federal Estate and Gift Taxation 310 (1942) (Lehman doctrine seen as application of Clifford principles to estate taxation); Note, 24 MINN. L. REv. 884 (1940) ; Callmann, The Lehman Doctrine, Its Significance and Application, 26 Taxes 233 (1948) (the concept of consideration in Lehman); cf. Marx, The Switching of Settlors in Intervivos Trusts, 26 TAxEs 622 (1948) (difficulties in applying the concept of consideration); for a possible extension of the Lehman doctrine, see Note, 48 Cor. L. REv. 450 (1948). 
ship are sufficient ${ }^{5}$ the courts require more, but have not been clearly articulate as to the identity of these necessary additional facts.

Trusts are not included in decedents' estates if the decedents did not actually, or constructively via reciprocal trusts, retain rights or powers ${ }^{b}$ which would justify inclusion under the Internal Revenue Code. The reciprocal problem arises when it is clear that the nominal grantor did not retain such rights or powers, but that another person did; the question is whether the reciprocal trust doctrime ought to be invoked to cause inclusion of the trust in the gross estate of the person holding the rights and powers. At this point, examination of the facts indicative of reciprocity becomes important.

\section{Events Surrounding Creation}

Not the terms of the trust instruments, crossing rights and powers among settlors, ${ }^{8}$ but the events leading to the trust instruments have become the principal criteria of reciprocity. ${ }^{9}$ There seems no doubt that the exchange of similar powers over trusts of almost simultaneous creation by settlors of close kinship gives rise to an inference of reciprocity. ${ }^{10}$ Judge Frank, keenly conscious and precisely articulate as to the judicial process, has declared that this inference of reciprocity must stand unless clear evidence positively shows no concert of action, but a "purely chance concurrence of several events."11

However, the nature and quantity of evidence needed to tilt the judicial scale away from an inference of reciprocity is far from clear. An inference of no concerted action may be created by facts indicative of independent action, such as the failure of one grantor to ever mention the other's trust, ${ }^{12}$ lack of participation in each other's plans, ${ }^{13}$ creation at different times, ${ }^{14}$ lack of a prior agreement on creation or provisions of the trust. ${ }^{15}$

5 See Estate of Arnold Resch, 20 T.C. 171 (1953).

6 See note 2 supra.

7 Commissioner of Int. Rev. v. Dravo, 119 F.2d 97 (3d Cir. 1941) ; accord, Tobin v. Coinmissioner of Int. Rev., 183 F.2d 919, 921 (5th Cir. 1950) (income tax; "the Tax Court has disregarded the plain language of the trust instruments") ; (f. Estate of Carolyn Peck Boardman, 20 T.C. No. 123 (CCH Dec. 19,823) (1953) (estate conceded reciprocity, argued lack of even constructive right to income).

${ }^{8}$ See text, Crossed Income and Crossed Powers, intra.

${ }^{9}$ See Estate of Louise D. Ruxton, 20 T.C. 487 (1953), "That concept [reciprocal or crossed trusts] is based on reason and analysis where the facts and circumstances of a particular case warrant going outside the formal terms of a trust instrument . ..." (emphasis added).

10 See Orvis v. Higgins, 180 F.2d 537 (2d Cir.), cert. denied, 340 U.S. 810 (1950) ; Coinmissioner of Int. Rev. v. Warner, 127 F.2d 913 (9th Cir. 1942) ; cf. Estate of Samuel S. Lindsay, 2 T.C. 174, 179 (1943), "But the facts that the trusts were executed about the same time, were in substantially equal amounts, and had similar provisions are not conclusive that the trusts were interdependent and were executed in consideration of each other."

11 Orvis v. Higgins, 180 F.2d 537, 540 (2d Cir.), cert. denied, 340 U.S. 810 (1950).

12 See Estate of Samuel S. Limdsay, 2 T.C. 174 (1943).

13 See Estate of Louise D. Ruxton, 20 T.C. 487 (1953) (no substantial participation; trust not included); cf. Newberry's Estate v. Commissioner of Int. Rev., 201 F.2d 874 (3d Cir. 1953) (participation; trust not included). But cf. Estate of John H. Eckhardt, 5 T.C. 673 (1945) (contention of no mutual participation rejected).

14 See In re Lueders' Estate, 164 F.2d 128 (3d Cir. 1947) (15 months apart) ; cf. Estate of Carolyn Peck Boardman, 20 T.C. No. 123 (CCH Dec. 19,823 (1953) (substantially later date addition included).

15 See Estate of Arnold Resch, 20 T.C. 171 (1953) ; accord, Lewis W. Wclch, 8 T.C. 1139 
On the other hand, factual events supporting the Commissioner have been: A prior agreement between the grantors, ${ }^{10}$ mutual planning, ${ }^{17}$ use of the same attorney and trustees, ${ }^{18}$ a prior gift of the trust corpus, ${ }^{19}$ creation at the same time, ${ }^{20} a$ relationship of mutual trust and confidence between the grantors. ${ }^{21}$

None of these facts are in themselves determinative; the impression created by the sum of facts presented by each side is reflected in the decision. $^{22}$

Most courts accord the Commissioner's inference of reciprocity a presumption of correctness, ${ }^{23}$ in accord with well-established policy. ${ }^{24}$ The Third Circuit, however, not only denies the Commissioner a favorable inference, but puts upon him the burden of proof. ${ }^{25}$ The Third Circuit theory is that the proponent of a common law relationship has the burden of proof, that reciprocal trusts are the creatures of common law contracts and the concept of "consideration," and that therefore the Commissioner, as the proponent, has the burden of proof. ${ }^{26}$

\section{Motive for Creation}

[W]ith few exceptions the law attaches legal consequences to what parties do, quite independently of their private purpose or intent.

Though this statement was quoted in a reciprocal trust case, ${ }^{27}$ its application to the reciprocal trust problem is itself an exception. Grantors'

(1947) (income tax) ; cf. Commissioner of Int. Rev. v. McLean, 127 F.2d 942 (5th Cir. 1942) (gift tax upheld when spouses failed to prove prior agreement indicating consideration).

${ }^{16}$ See Blackman v. United States, 48 F. Supp. 362 (Ct. Cl. 1943).

17 See Estate of John H. Eckhardt, 5 T.C. 673 (1945) ; cf. Newberry's Estate v. Commissioner of Int. Rev., 201 F.2d 874 (3d Cir. 1953); Estate of Arnold Resch, 20 T.C. 171 (1953) (consultation and cooperation by husband not enough to show reciprocity).

18 See Estate of Grace D. Simclaire, 13 T.C. 742 (1949) (same witnesses, notary, type of paper, and print); cf. In re Lueders' Estate, 164 F.2d 128 (3d Cir. 1947) (same attorney; not included).

10 Cf. Estate of Arnold Resch, 20 T.C. 171 (1953) (gift by husband immediately prior to creation not sufficient to show reciprocity in absence of agreement as to disposition of gift).

20 See Hanauer's Estate v. Commissioner of Int. Rev., 149 F.2d 857, 858 (2d Cir. 1945), cert. denied, 326 U.S. 770 (1946), ". . same occasion and at same time ...."; see Estate of John H. Eckhardt, 5 T.C. 673 (1945) (6 days apart; included in gross estate) ; cf. Estate of Carolyn Peck Boardman, 20 T.C. No. 123 (1953) (substantially later addition included). But cf. Newberry's Estate v. Commissioner of Int. Rev., 201 F.2d 874 (3d Cir. 1953) (executed and amended at same time; not included in gross estate).

21 See Estate of Carrie Stark Newberry, 6 T.C.M. 455 (1947), aff'd per curiam, 172 F.2d 220 (3d Cir. 1948).

22 See Orvis v. Higgins, 180 F.2d 537 (2d Cir. 1950), cert. denied, 340 U.S. 810 (1950).

23 E.g., Commissioner of Int. Rev. v. Warner, 127 F.2d 913 (9th Cir. 1942); Estate of John H. Eckhardt, 5 T.C. 673 (1945).

24 Cf. Oliver, The Nature of the Compulsive Effect of State Law in Federal Tax Proceedings, 41 CALIF. L. REv. 638, 667 and notes 154, 155, 156 (1953).

25 In re Lueders' Estate, 164 F.2d 128 (3d Cir. 1947); also see Newberry's Estate v. Commissioner of Int. Rev., 201 F.2d 874 (3d Cir. 1953), 66 HARv. L. Rev. 1319 (1953).

${ }^{26}$ For a descriptive analysis of the general effect of state law on the burden of proof in federal tax cases, see Oliver, supra note 24 , at 667 .

27 Cole's Estate v. Commissioner of Int. Rev., 140 F.2d 636, 638 (8th Cir. 1944), quoting Richardson v. Smith, 102 F.2d 697, 699 (2d Cir. 1939). 
motives are almost always considered; are irrelevant only when their fulfillment does not necessitate creation of reciprocal trusts. Mutual desires to travel, ${ }^{28}$ worry over economic conditions, ${ }^{20}$ wishes to keep property in the family, ${ }^{30}$ hopes of shedding management responsibilities, ${ }^{31}$ and concern for thrift and prudence ${ }^{32}$ may make creation of trusts desirable and sensible, but in no way call for reciprocal trusts. Evidence indicating these motives does not upset the Commissioner's case.

On the other hand, circumstances may motivate grantors to create similar trusts individually at about the same time. Situations may arise where creation of a trust with powers or rights in a spouse or relative are the best solution to the grantor's problems, and these events and the motivations to which they gave rise can be used to defeat reciprocity.

Examples of motives indicating independent action have been: A wife's desire to provide an income for her husband after his bank collapsed, and his simultaneous desire to insure an income to their daughters; ${ }^{33}$ a young wife's desire to provide for her future, and her husband's wish to make a safe and prudent investment. ${ }^{34}$

Occasionally, circumstances indicate that tax avoidance could have been the only possible motive for designation of the nominal grantor. In these cases, decedents' motives inure to the benefit of the treasury. ${ }^{35}$

Using a distinctively unique approach, the Court of Appeal for the Third Circuit does not fit into the foregoing analysis; it apparently regards any motive other than tax avoidance as indicative of no reciprocity. ${ }^{30}$

\section{Creation in Consideration for Each Other}

A person who furnishes the consideration for the creation of a trust is the settlor, even though in form the trust is created by another.

With these words the concept of reciprocal trusts was born, ${ }^{37}$ and without doubt the most spectacular ${ }^{38}$ obstacle to ascertaining reciprocity has

28 See Orvis v. Higgins, 180 F.2d 537 (2d Cir.), cert. denied, 340 U.S. 810 (1950), and the opinion of the lower court, 80 F. Supp. 64 (S.D.N.Y. 1948).

29 Ibid.

30 See Cole's Estate v. Commissioner of Int. Rev., 140 F.2d 636, 638 (8th Cir. 1944), "Assuming that retention of ownership of the stock in the family was a motive of each of the decedents in creating the trusts, to accomplish such purpose it was unnecessary to give to each other a life interest in the income of each other's stock."

31 See Estate of John H. Eckhardt, 5 T.C. 673 (1945) (alleged motive not believed).

32 See Carrie S. Newberry Estate, 6 T.C.M. 455 (1947), aff'd per curiam, 172 F.2d 220 (3d Cir. 1948).

33 See Estate of Louise B. Ruxton, 20 T.C. 487 (1953).

34 See Estate of Arnold Rescb, 20 T.C. 171 (1953).

35 See Estate of Grace D. Simclaire, 13 T.C. 742 (1949) (beneficiary of a trust transferred almost entire interest to her father, who immediately created second trust; beneficiary held grantor of second trust); Blackman v. United States, 48 F. Supp. 362 (Ct. Cl. 1943) (decedent held grantor of second trust created pursuant to his waiver of rights on termination of first).

36 See Newberry's Estate v. Commissioner of Int. Rev., 201 F.2d 874 (3d Cir. 1953), 66 HARV. L. REv. 1319 (1953) (power to shift interests crossed because children were young, had not yet chosen mates; not reciprocal).

3r Lehman v. Commissioner of Int. Rev, 109 F.2d 99, 100 (2d Cir. 1940), quoting Scorr, TRUSTS \& 156.3 (1939).

38 Compare the language of In re Lueders' Estate, 164 F.2d 128 (3d Cir. 1947) with Surrey and Warren, CCH FED. TAXES, Current Law and Practice II 2544 (1953); cf. Marx, supra note 4. 
been uncertainty and disagreement as to the meaning of "consideration" in this tax sense.

In spite of a torrent of words from bench ${ }^{39}$ and commentators ${ }^{40}$ as to the role of "consideration," it appears that the Tax Court and all save one of the Federal Courts of Appeal which have passed on the question in reality have used "consideration" in the reciprocal trust context as a term descriptive of the decision, the ultimate imference, in each case. ${ }^{41}$ Whether trusts were "executed in consideration" or "not executed in consideration" has expressed the final inference created by the trust instrument and the circumstances surrounding its creation..$^{42}$

Needless to say, this loose usage has created confusion. ${ }^{43}$ While "consideration" in the commercial sense embodies a bargained for exchange ${ }^{44}$ and perhaps equivalency of value, ${ }^{45}$ most courts have not required a showing that one grantor's transfer induced the other's, ${ }^{40}$ and have found reciprocity in the absence of reciprocated powers mutually beneficial to the grantors. ${ }^{47}$

Shifting usage has enabled the Commissioner to equate "consideration" with net effect in estate tax cases, where a broad concept is to his advantage, but has enabled him to impose strict requirements in gift tax cases, where his interests he in the opposite direction. ${ }^{48}$

In sharp contrast, "legal consideration" is required by the Third Circuit: "[P]ayment for the creation of a trust by another must be real if the alleged payor rather than the apparent settlor is to be treated as grantor of

39 Compare Newberry's Estate v. Commissioner of Int. Rev., 201 F.2d 874 (3d Cir. 1953) with the Tax Court opinion, Estate of Myrtle H. Newberry, 17 T.C. 597 (1951).

40 See note 4 supra.

41 See Orvis v. Higgins, 180 F.2d 537 (2d Cir.), cert. denied, 340 U.S. 810 (1950); Hanauer's Estate v. Commissioner of Int. Rev., 149 F.2d 857 (2d Cir. 1945), cert denied, 326 U.S. 770 (1946) ; Cole's Estate v. Commissioner of Int. Rev., 140 F.2d 636 (8th Cir. 1944); Estate of Louise D. Ruxton, 20 T.C. 487 (1953); Estate of Arnold Resch, 20 T.C. 171 (1953); Estate of Grace D. Sinclaire, 13 T.C. 742 (1949); Estate of John H. Eckhardt, 5 T.C. 673 (1945); Estate of Frederick S. Fish, 45 B.T.A. 120 (1941) ; accord, Werner A. Wiedboldt, 5 T.C. 946 (1945) (income tax).

42 This use of "consideration" seens consistent with Professor Corbin's statement, "[T]he use of the term can not be avoided; but, in making use of it, it is necessary to consider the purpose for which it is used and to make sure that justice is not being defeated by using it in accordance with some narrow and limited definition." 1 CorbIn, Contracts 344 (1950).

43 See, e.g., the attempt to distinguish this loose concept of "consideration" from a noconsideration doctrine in Cole's Estate v. Commissioner of Int. Rev., 140 F.2d 636 (8th Cir. 1944).

44 Restatenient, Contracts $\$ 75$ (1932); cf. 1 Corbin, Contracts $\$ \S 114,116$ (1950).

45 See 1 id. \$117.

46 See cases cited note 41 supra.

47 See Estate of Grace D. Simclaire, 13 T.C. 742 (1949); see Estate of Myrtle H. Newberry, 17 T.C. 597, 606 (1951), "[I]t appears clear that it is not necessary that the reciprocated powers be beneficial, or constitute a quid pro quo in the sense of equivalency in value...", rev'd sub nom. Newberry's Estate v. Commissioner of Int. Rev., 201 F.2d 874 (3d Cir. 1953); cf. Estate of Louise D. Ruxton, 20 T.C. 487 (1953).

48 See Commissioner of Int. Rev. v. McLean, 127 F.8d 942 (5th Cir. 1942); Commissioner of Int. Rev. v. Warner, 127 F.2d 913 (9th Cir. 1942). 
the trust." ${ }^{49}$ The doctrine of reciprocity is applicable only when the Commissioner can prove that the trusts were the quid pro quo of a bargained for exchange between the grantors.

However, as the Third Circuit has itself recognized, "In the normal case ... it is a distortion of meaning to say that the action of one spouse is a quid pro quo inducing the action of the other." "Fo Furthermore, "A bargain and exchange within the meaning of the Lehman doctrine may exist, yet be unprovable." 51

The conflict between loose and strict concepts of "consideration" appears to reveal a basic difference in approach to the problem of reciprocity. While the majority of courts seemingly regard the doctrine as closing an avoidance device left unmentioned by the specific language of the Code, ${ }^{52}$ the legal consideration approach is subject to an opposite analysis. It can be fitted specifically within the Internal Revenue Code parenthetical expression, "(except in case of a bona fide sale for an adequate and full consideration in inoney or money's worth)." 53 If trusts liave been created in a bona fide sale, in consideration for eacli other, the grantors' estates ought to include the proceeds.

While the Tax Court recognizes this statutory analysis, ${ }^{54}$ it has indicated that it regards the reciprocity doctrine as going beyond it, into the area uncliarted by specific statutory language. ${ }^{55}$

The Third Circuit somewhat regretfully feels that the tax loopholes left by its strict approacl must exist until Congress acts, ${ }^{56}$ but it appears that Congress has already sanctioned the realistic approach of the Tax Court and the other Federal Courts of Appeal. When allowing a limited time for tax-free recission of reciprocal trusts, ${ }^{57}$ both House and Senate took occasion to illustrate taxable reciprocal trusts. ${ }^{58}$ All examples predicated taxability not upon the existence of legal consideration, but upon the retention of effective economic control.

49 Newberry's Estate v. Commissioner of Int. Rev., 201 F.2d 874, 877 (3d Cir. 1953); also see In re Lueders' Estate, 164 F.2d 128 (3d Cir. 1947).

50 Newberry's Estate v. Commissioner of Int. Rev., 201 F.2d 874, 877 (3d Cir. 1953).

51 Id. at 878 .

52 See, e.g., Hanauer's Estate y. Commissioner of Int. Rev., 149 F.2d 857 (2d Cir. 1945), cert. denied, 326 U.S. 770 (1946); Cole's Estate v. Commissioner of Int. Rev., 140 F.2d 636 (8th Cir. 1944); Estate of Louise D. Ruxton, 20 T.C. 487 (1953).

53 INT. REv. CoDE $\$ \S 811$ (c), 811(d). The parenthetical expression exempts persons within its terms from the mclusionary provisions applicable to trustors who retain rights or powers over income or corpus.

54 See Estate of Henry H. Scholler, 44 B.T.A. 235 (1940) (mutual transfers in trust held a sale; trust received included in transferor's gross estate).

65 See the opinion in Louise D. Ruxton 20 T.C. 487 (1953).

56 See Newberry's Estate v. Commissioner of Int. Rev., 201 F.2d 874, 878 (3d Cir. 1953).

57 Technical Changes Act of 1949, 63 STAT. 893 \& 6 (1949).

58 H. R. Rep. No. 920, 81st Cong., 1st Sess. 6 (1949) ; SEN. Rep. No. 831, 81st Cong., 1st Sess. 5 (1949); Speech of Senator George, Chairman, Sen. Finance Comm., 95 Cong. Rec. 12989 (1949). 


\section{Similar Amounts}

All courts agree that reciprocal trusts, once found, are such only to the extent of the smaller corpus when the corpora are unequal in size. ${ }^{59}$

As to indicating reciprocity: While even great disparity in size has not prevented finding reciprocity ${ }^{60}$ similar or equal amounts appear to have helped create an inference favorable to the Commissioner. ${ }^{\text {ix }}$ On the other hand, when other factors indicated that the trusts were not "crossed," equality of corpora has not in itself supported reciprocity. ${ }^{62}$ In Estate of Samuel S. Lindsay $y^{63}$ husband and wife had created trusts of substantially equal amounts, but the Tax Court, on the basis of the events surrounding execution, found no reciprocity, and stated that equality of amount is not conclusive of interdependence. ${ }^{04}$

\section{The Malleable Trustee}

In reciprocal trust litigation, as in other areas of estate taxation, the possibility of a malleable trustee has been given scant acknowledgment. Solne cases have implied that a simultaneous exchange of trusteeships helps create an impression of reciprocity ${ }_{9}^{65}$ but, on the other hand, language incorporating adequate standards into the trust instrument has been accepted as controlling the conduct of even close familial relations. ${ }^{66}$

Further, in spite of the possibility of unwritten control by the grantors, no court ever appears to have questioned the reality of crossed trusts. (By contrast, other types of trusts allowing possibilities of control, as where the

E0 See, e.g., Cole's Estate v. Commissioner of Int. Rev., 140 F.2d 636 (8th Cir. 1944); Estate of Frederick S. Fish, 45 B.T.A. 120 (1941).

CO See Orvis v. Higgins, 180 F.2d 537 (2d Cir.), cert. denied, 340 U.S. 810 (1950); cases cited note 59 supra.

61 See Hanauer's Estate v. Commissioner of Int. Rev., 140 F.2d 857 (2d Cir. 1945), cert. denied, 326 U.S. 770 (1946) ; Estate of John H. Eckhardt, 5 T.C. 673 (1945) ; Estate of Samuel S. Lindsay, 2 T.C. 174 (1943); accord, Werner A. Wieboldt, 5 T.C. 946 (1945) (income tax); cf. Louise D. Ruxton, 20 T.C. 487 (1953) (similar amounts, but no reciprocity because the same rights and powers were not exchanged).

62 Newberry's Estate v. Commissioner of Int. Rev., 201 F.2d 874 (3d Cir, 1953); Estate of Samuel S. Limdsay, 2 T.C. 174 (1943); accord, Lewis W. Welch, 8 T.C. 1139 (1947) (income $\operatorname{tax})$.

632 T.C. 174 (1943).

64 Supra note 63 at 179.

65 See Hanauer's Estate v. Commissioner of Int. Rev., 149 F.2d 857 (2d Cir. 1945), cert. denied, 326 U.S. 770 (1946) (spouse and daughter's husband as trustees); Counmissioner of Int. Rev. v. Warner, 127 F.2d 913 (9th Cir. 1942) (brothers, attorney, trust company as trustees; gift tax imposed); Lewis W. Welch, 8 T.C. 1139 (1947) (husband sole trustor; mcome tax imposed).

66 See Commissioner of Int. Rev. v. Dravo, 119 F.2d 97 (3d Cir. 1941) ("advance" of principal as trustees deemed advisable held adequate standard; no reciprocity); Estate of Louise D. Ruxton , 20 T.C. 487 (1953); Estate of Samuel S. Lindsay, 2 T.C. 174 (1943) (son and corporate trustees); cf. the dissent of Biggs, J., in Commissioner of Int. Rev. v. Dravo, 19 F.2d 97, 100 (3d Cir. 1941) ; Tobin v. Commissioner of Int. Rev., 183 F.2d 919, 921 (5th Cir. 1950), "the Tax Court has disregarded the plain language of the trust agreements ...." (income tax not imposed) ; Estate of John H. Eckhardt, 5 T.C. 673 (1945) (spouse and daughter trustees; grantors were life beneficiaries; trust included in gross estates under reciprocity). 
grantor has retained both legal and equitable title, have been subject to the Commissioner's attack as being unreal). ${ }^{67}$

In view of these judicial tendencies to respect the crossed trust and to recognize in the trustee only those powers specified in the trust instrument, an estate may avoid reciprocity entirely. Trusts may be drawn binding the trustees by explicit standards, and, even if "crossed," may not be held "in effect" to have left in the grantors that control which would warrant inclusion in their gross estates. ${ }^{.8}$

\section{Crossed Income and Crossed Powers}

Inasmuch as retention of the right to income, power over beneficial interests or power to ainend or terminate would cause inclusion of a trust in an individual settlor's gross estate, ${ }^{6 \theta}$ it would seem probable that when several settlors simultaneously exchanged such rights or powers, the courts would be quick to take notice. ${ }^{70}$ In reality, while crossed rights or powers have apparently added to the inference of reciprocity, ${ }^{71}$ little judicial comment has been directed toward them. ${ }^{72}$

However, a recent decision of the Tax Court, ${ }^{73}$ in finding reciprocity "untenable," relied upon an absence of similarly crossed rights and pow-

67 See Commissioner v. Goodan, 195 F.2d 498 (9th Cir. 1952), including the opinion of the dissent, supra at 498, and the opinion of the Tax Court, 12 T.C. 817 (1949). For an analysis of this case as illustrative of theories of compulsive effect of state law in federal taxation, see Oliver, supra note 24 at 653.

68 Compare Commissioner of Int. Rev. v. Dravo, 119 F.2d 97 (3d Cir. 1941) bolding sufficiently definite to give settlor no real control over corpus, "Advance portions of the principal hereof to or for the use or benefit of the Creator's said husband (wife), at such times, in such amounts and for such purposes as the said Trustees in their opinion may deem advisable," with Estate of Carolyn Peck Boardman, 20 T.C. No. 123 (CCH Dec. 19,823) (1953), holding dispersal of income for the "comfort, support, and/or happiness" of the simultaneous grantor not an explicit enough standard to avoid inclusion.

${ }^{60}$ See note 2 supra.

70 Guidance from the U.S. Supreme Court came in Higgins v. Smith, 308 U.S. 473, 477 (1940), "The government may look at actualities and upon determination that the form employed for doing business or carrying out the challenged tax event is unreal or a sham may sustain or disregard the effect of the fiction as best serves the purposes of the tax statute." Calin, Local Law in Federal Taxation, 52 YaLE L. J. 799, 815. (1943), regarded the Lehman doctrine as iniporting general equity concepts to bulwark concepts peculiar to taxation. See the comparison of dispositive techniques open to the unan of property with pragmatic techniques available for tax analysis made by Oliver, Property Rationalism and Tax Pragmatism, 20 Texas L. REv. 675 (1942).

71 Crossed income indicative of retained econounic mastery: Cole's Estate v. Commissioner of Int. Rev., 140 F.2d 636 (8th Cir. 1944); Estate of Frederick S. Fish, 45 B.T.A. 120 (1941).

72 Crossed incone but no reciprocity: In re Lueders' Estate, 164 F.2d 128 (3d Cir. 1947); Estate of Samuel S. Lindsay, 2 T.C. 174 (1943).

Opinions finding reciprocity without special attention to crossed income or crossed powers: Orvis v. Higgins, 180 F.2d 537, 541 (2d Cir.), cert. denied, 340 U.S. 810 (1950), "The coincidental occurrence of these events would be highly improbable"; Hanauer's Estate v. Commissioner of Int. Rev., 149 F.2d 857 (2d. Cir. 1945), cert. denied, 326 U.S. 770 (1946); Cole's Estate v. Commissioner of Int. Rev., 140 F.2d 636 (8th. Cir. 1944); Estate of Grace D. Sinclaire, 13 T.C. 742 (1949); Estate of John H. Eckhardit, 5 T.C. 673 (1945). See text, Events Surrounding Creation, supra. But cf. In re Lueders' Estate, supra.

73 Estate of Louise D. Ruxton, 20 T.C. 487 (1953). 
ers. $^{74}$ Thus it appears that crossed rights or powers are prerequisite of reciprocity, but not conclusive of its existence.

\section{Conclusion}

Estate and gift taxation is a process in which long established dispositive devices, operating with mathematical precision and replete with timeencrusted terminology, are constantly pushed before the pragmatic scrutiny of the tax gatherer ${ }^{75}$ Society has an interest, on the one hand, in maintaining for the person of property convenient means for the disposition and distribution of his wealth, free of uncertainty and confusion. ${ }^{76}$ On the other hand, society has an interest in maintaining a federal tax system of fiscal ${ }^{77}$ justice and national uniformity. ${ }^{\text {is }}$ Persons of equivalent economic position, wherever their location in the nation, should receive equivalent tax treatment.

Present opmion agrees that these objectives cannot be met by euphemistic generalities ${ }^{79}$ nor by cavalier attempts to dismiss common law dispositive terminology $\mathrm{m}$ tax litigation, ${ }^{80}$ nor by employment of common law terminology as an analytical tool for tax purposes. ${ }^{81}$

Instead, for tax purposes, an inductive, ad hoc approach should be made to each situation. The question should be directly faced: Is this relationship, or this dispositive device, to be taxed? ${ }^{82}$

When subjected to this analysis, family reciprocal trusts, crossing rights and powers among the grantors, appear to weigh lightly among the well-

74 The income of the trust created by the wife went to the husband, while that of the trust created by the husband went to the couple's daughters, then over to the wife. In rejecting reciprocity, the court emphasized that uncrossing the trusts would not leave each grantor with the same right in or power over the respective properties transferred.

io See the fine analysis by Ohiver, Property Rationalism and Tax Pragmatism, 20 Texas L. REv. 675 (1942).

70 But cf. "Judged by its effects on distribution, our system of inheritance is clearly indefensible on economic grounds," WedgewOod, The Econonacs of INEERITANCE Part II, ch. VIII § 2 (1929); "the institution of inheritance promotes social stratification through its indirect effects not less than through its direct," 2 TAUSSIG, PrIncIPIEs of Econonacs 248 (1925); "For ny own part, I beheve that there is social and phychological justification for significant inequalities of income and wealth, but not for such large disparities as exist today," Keynes, The General Theory of EArploxarent Interest and Money 374 (1935).

77 Though often used to mean justice between persons, the term in its inore techmeal sense means a tax system oriented toward full utilization of resources. See KEYNES, op. cit. supra note 76 at 373, "The existing confusion of the public mind on the matter is well illustrated by the very common behef that the death duties are responsible for a reduction in the capital wealth of the country."

78 See Oliver, The Nature of the Compulsive Effect of State Law in Federal Tax Proceedings, 41 CALIF. L. Rev. 638, 640 (1953).

79 See Rice, Judicial Techniques in Combating Tax Avoidance, 51 Micr. L. Rev. 1021, 1051 (1953).

s0 See Ohver, Federal Tax Significance of State Law: A Study of the Areas of Influence, Major Tax Problems of 1953 483, 517, ProceEdngs of the Tax Institute of tee UNIVERSITY of SOUTHERn CALIFORNIA (1953); Oliver, The Nature of the Compulsive Effect of State Law in Federal Tax Proceedings, 41 CaLIF. L. Rev. 638 (1953).

81 See Oliver, Property Rationalism and Tax Pragmatism, 20 Texas L. Rev. 675 (1942).

82 "It is desirable that within its sphere the judiciary should consider operationally and by imagined experiment the social consequences of its tax decisions." Id. at 709. 
established dispositive devices society desires to protect. They seem, instead, attempts to hide taxable economic powers behind the formal concepts of trust law. The judicial doctrime of reciprocal trusts represents a justifiable technique to subject these powers to tax assessment, avoiding a rigid formalism which would destroy public confidence in the justice of federal tax administration. ${ }^{83}$

Therefore there appears little reason to import the commercial concept "consideration" (already undergoing transformation to meet commercial needs) $)^{84}$ to ascertain taxability of allegedly reciprocal trusts. Writing in terms of "consideration" creates confusion in estate and gift taxation, may have adverse repercussions in commercial affairs, and perpetuates the gulf between gift and estate taxes, to the distress of both treasury and taxpayer. ${ }^{85}$ Yale M. Lyman

${ }^{83}$ See Rice, supra note 79, at 1051.

84 See 1 Corbin, Contracts $\$ \$ 109-118$ (1950); Restatemaent, Contracts $\S 90$ (1932).

85 See Surrey, An Introduction to Revision of the Federal Estate and Gift Taxes, 38 CALT. I. REv. 1 (1950); Groves, Retention of Estate and Gift Taxes by the Federal Government, 38 Caurr. L. REv. 28 (1950); DeWind, The Approaching Crises in Federal Estate and Gift Taxation, 38 CAIIF. L. REv. 79 (1950) ; cf. Snyder, "A Proposal for Integration and for Correlation with the Income Tax," Hearings Before Committee on Ways and Means on Proposed Revisions of the Internal Reverne Code, Federal Estate and Gift Taxes, 80th Cong., 1st Sess. 3798 (1947). 